\title{
UNDERSTANDING THE FACTORS WHICH ENGAGE FEMALE PARTICIPATION IN PATENTS IN ANDALUSIA (SPAIN)
}

\author{
Carmen Puentes Graña*, Rosario Toribio Muñoz**
}

\begin{abstract}
Background: One economic dimension of sustainable development is innovation. If we understand the innovative capacity of a country as the ability to achieve economic growth, social welfare, and sustainability, the human factor is key to managing these objectives; in particular the contributions of scientists. Gender differences in science and technology remain stable over time. However, there have been very few studies of the specific involvement of women in technological innovation.. From 1990 to 2006 there were 411 women and 1427 men patenting in universities and public research centres in Andalusia (Spain).
\end{abstract}

Research aims: The aim of this article is to determine which factors encourage female participation in patent activity.

Methodology: The research is based on the analysis, by estimating Logit and Probit models, of information that shows 498 patent applications and 1838 inventors from universities and public research centres (CSIC), in Andalusia (Spain) between 1990 and 2006.

Key finding: The variables that have emerged as significant and positive regarding the probability of female participation are the number of authors in each patent, the chemical sector, and the share of Ph.D. holders included in patent teams. Elements that do not appear to be relevant in explaining the probability of female presence in patents are the collaboration between different research centres and the number of patent assignments an individual has in the International Patent Classification.

Keywords: gender and patents, innovation, female presence.

* Universidad de Cádiz. E-mail: carmen.puentes@uca.es

** Universidad de Cádiz. E-mail: rosario.toribio@uca.es 


\section{INTRODUCTION}

Invention and human capital are undeniable factors in economic growth (Mariani \& Romanelli, 2007). Innovation is directed by knowledge, and knowledge dwells in individuals. However, studies of the specific involvement of the inventor in technological innovation are very scarce. It is crucial to consider the human factors of innovation in order to understand and manage the innovation process (Jung \& Ejermo, 2014). The investigations of Hanson (1996) and Pearson and Fechter (1994) note that, as human resources, women are important to the size, creativity, and diversity of the scientific and engineering workforce (cited in Fox, 2010, p. 998). Investigating aspects of gender in invention suggests possibilities for more efficient use of human resources. However, studies concerning the analysis of women's participation in technological research are very limited. The lack of studies may be, as Agnete Alsos et al. (2013) highlighted, because people in innovation are seemingly invisible. But this fact does not imply that gender and people are irrelevant to understanding the innovation process.

The under-representation of women in science and technology in the European Union causes special concern, considering that there is both a low percentage of women researchers and an even lower percentage of women inventors (Busolt \& Kugele, 2009). This means that the underemployment of the talent, knowledge, and skills of women weighs heavily in the science system (Kugele, 2010) and should be addressed. In the USA Hunt et al. (2012), quantified women's under-representation, stating that abolishing the gap in participation between males and females in science and engineering areas would increase GDP per capita by $2.7 \%$, and commercialised patents by $24 \%$.

For all of the reasons given above, it is essential to understand the factors fostering female participation in invention. This paper will try to shed light on this topic and find a response to the following question:

Which factors encourage female participation in patents?

The article is structured as follows: Section 2 reviews the existing literature regarding studies of women's engagement in patenting activity. The data, estimations, and results are presented in sections 3 to 5. Finally, the most relevant conclusions are highlighted in section 6 . 


\section{BACKGROUND}

One economic dimension of sustainable development is based on innovation, and the creation of knowledge and innovation must be understood as a process. In this process, the individual's knowledge is increased and internalised as a part of organisational knowledge (Nonaka, 1991). Innovation is done by scientists or by teams of inventors. Gender differences in science and technology remain stable over time. However, there have been very few studies of the specific involvement of women in technological innovation. This analysis outlines a problem due to the small number of women represented and, in many cases, the difficulty in obtaining gender-disaggregated data.

Despite a relative lack of data, important advances are being made in the study of women's contributions to technological development. For example, among scientists in the U.S. life sciences' fields, the share of patents made by women faculty researchers is lower than $40 \%$ that of men (Ding et al., 2006). The work of Azoulay et al. (2007) yields the same results. Thursby and Thursby (2005) examined the field of engineering over 17 years, finding gender differences in patenting and concluding that the probability of patenting something is $43 \%$ higher for men than for women. McMillan (2009), analysed different topics in the U.S. biotechnological industry such as female participation in technological knowledge, the quality of patents made, and the transfer of knowledge between science and technology. One of his most notable conclusions is that although women patent less frequently than men, the quality of patents whose authors are solely women is higher than patents whose authors are men or patents applied for jointly by men and women. Other studies support McMillan's results; for example, the work done by Whittington and Smith-Doerr (2005): Women patent less often than men, but the quality of their patents is better. Two recent investigations (Okoń-Horodyńska \& Zachorowska-Mazurkiewicz, 2015; Toribio \& Puentes, 2016) highlight how important the interaction between female and male researchers is. The first study notes that "working in pairs, men and women also do a better job of expressing jointly-developed new ideas." The results of the second work are similar: "the quality of the patent is higher when there are both males and females present in the team of inventors." Based on the results discussed above, patent activity results seem to be linked to gender. 
The under-representation of women in science and technology in the European Union causes special concern. Besides the low percentage of women researchers, there is an even lower percentage of women inventors (Busolt \& Kugele, 2009). Innovation is an important part of the 2020 European Strategy. One key point of the strategy is recruiting and retaining women in scientific and technical fields (Okoń-Horodyńska \& Zachorowska-Mazurkiewicz, 2015). Among comparative studies between different countries we can highlight Naldi et al. (2005), who implemented analyses of six European countries (the countries analysed are Germany, Spain, Italy, France, United Kingdom, and Sweden.) One of his outstanding results is the fact that the scientific activity of women is higher in number of publications than the number of patents. This author also finds that Spain is a country with a higher percentage of women inventors. Similarly, Frietsch et al. (2009), compared 14 countries, concluding that in all of them the presence of women in patent applications is rising but it is still lower than that of men. They highlight that Spain has a high involvement of females in patenting. Wisła and Sierotowicz (2015) analysed patent activity in the 28 European countries belonging to the European Union from 1999 to 2013, concluding that female patent inventors are growing in all of the countries included in the study and the share of men is decreasing.

In the case of Spain, Mauleón and Bordons (2010) researched this topic over 16 years in universities and the Spanish National Research Council. The results indicate that only $16 \%$ of the patents analysed include a woman among its inventors, with a $9 \%$ contribution to technological output. The low female involvement in technology is focused on specific institutional sectors (public research institutions) and technological sections (human necessities and chemistry.)

The same conclusion was reached by Bunker Whittington (Whittington \& Smith-Doerr 2005). This author found that gender disparities in publishing and patenting among life scientists are greater in academia than in industry. Morgan et al. (2001) noted that women who patent are more likely to be life scientists (43\%) than engineers (8\%), particularly among academics. But in industry, the results were very surprising: $32 \%$ of female engineers have patent activity, as do $28 \%$ of the female life scientists.

All the questions outlined above lead us to consider the factors that engage female researchers in patent activity. Little is known about 
this complex and little-analysed topic and there is little data on the subject. Our findings will lead to a better understanding of women's input to technological knowledge.

\section{DATA SOURCE}

We have constructed a database with the information obtained from the Spanish Patent Office related to all the patents applied for by universities and public research centres in Andalusia (Spain). In order to create this database we individually and manually extracted the information contained both in the patent application and in the State of the Art Report on the Technique (hereinafter referred to as SAR). The SAR is a document, drawn up exclusively by the Patent Office, with reference to a specific patent application. It supplies information regarding the originality of the invention to be patented. The analysis covers the period from 1990 to 2006. All of the patent applications (universe) were studied and all economic sectors taken into consideration. There were 489 in total. From patent applications we can obtain gender information concerning inventors. We count inventors based on their appearance in patents (full counts) instead of their contribution to patenting (fractional counts). The following information was gathered: number of inventors and their gender $(1,838,411$ female and 1,427 men), number of patents cited (951), number of scientific publication cited $(4,000)$, cooperation between different institutions, number of countries for which patent protection is requested, and the number of assignments in the international patent classification.

For examining the hypotheses, it is essential to know whether or not the authors hold a doctoral degree. Patent applications do not give personal information about this topic. This information was extracted from Teseo database of the Spanish Education Ministry, which collects data related to the theses presented in Spain. There were 560 male and 210 female PhD inventors during the period studied. The authors who earned their degrees abroad were found by searching personal information on the Web. After gathering data on the individuals, we combined it with the first dataset, the patent applications. 


\section{MODEL AND VARIABLES}

The question highlighted in the introduction leads us to consider the following hypothesis:

$\mathrm{H}_{1}$ : The number of inventors influences the number of females involved in the invention.

$\mathrm{H}_{2}$ : There are differences in female participation among technological sectors.

$\mathrm{H}_{3}$ : Female participation is different among universities and research centres in Andalusia.

$\mathrm{H}_{4}$ : The share of $\mathrm{PhDs}$ in patent teams affects female participation.

$\mathrm{H}_{5}$ : Collaboration between institutions influences female participation.

$\mathrm{H}_{6}$ : Technical characteristics of the patent influence female participation:

$\mathrm{H}_{6.1}$ : Non-patent citations act on female participation.

$\mathrm{H}_{6.2}$ : Citing patents affects female participation.

$\mathrm{H}_{6.3}$ : The number of IPC codes has an impact on female participation.

$\mathrm{H}_{6.4}$ : The number of countries where the patent is applied for helps determine female participation.

\section{Model:}

The basic models used to contrast our hypothesis, are LOGIT and PROBIT. This is due to the nature of the dependent variable, which can only take the values of one or zero.

$$
P(y=1 / x)=G\left(\beta_{0}+\beta_{1} x_{1}+\ldots+\beta_{k} x_{k}\right)=G\left(\beta_{0}+x \beta\right)
$$

\section{Variables:}

Dependent variable:

- $\quad\left(\right.$ female $\left._{i}\right)$ : Dummy variable. It is 1 if there is a female presence in the research team and 0 otherwise.

Explanatory variables:

These variables are classified in three groups: 
Patent characteristics:

- $\quad\left(\operatorname{lncp}_{i}\right)$ : Includes the patents cited in the central body of the patent document, allowing the measurement of the frameworks for the transfer of knowledge. (Criscuolo \& Verspagen, 2008; Hall et al., 2005). As McMillan (2009) highlights, there is a relationship between the number of backwards citations and gender: women cite fewer patents than men. We have collected a total of 951 patent citations. In order to reduce the dispersion we considered the variable in a natural logarithm. $\left(\operatorname{lnc} p_{i}\right)$.

- $\quad\left(\operatorname{lnnpc}_{i}\right)$ : Number of scientific citations or non-patent citations. This variable is frequently connected with basic research or the relation between science and technology (Narin et al., 1997). As McMillan (2009) suggests, female inventors quote science-based documents. Thus, we expect a positive relationship between the variables $n p c_{i}$ and female. We counted the number of scientific citations included in the patent application and found 4,000 citations. To reduce the dispersion we have taken the natural logarithm of the variable.

- $\quad\left(i p c_{i}\right)$ : Number of assignments in the International Patent Classification. The patents may be assigned different IPC codes, which were established by the Strasbourg Agreement in 1977: "It provides for a hierarchical system of language-independent symbols for the classification of patents and utility models according to the different areas of technology in which they perform." We could not find enough empirical literature that establishes a relationship between female participation and $i p c_{i}$. The findings of Meng and Shapira (2011) show us that female patents and mixed patents in nanotechnology, have more IPC classes than male patents.

- $\quad\left(\right.$ fsize $\left._{i}\right)$ : This variable shows the degree of extension and circulation of the patent, deciding on those countries where the invention is protected, taking into account that those countries have a greater capacity for developing the patents or that there are close lines of research. We could not find empirical literature that establishes a relationship between female participation and ssize $_{i^{*}}$

- $\quad\left(\right.$ chemic $\left._{i}\right)$ It is compulsory to distinguish this sector from the rest because women's involvement in patents is unequally distributed by technological sections. In particular, most of the 
female researches in Spain are working on patents related to the chemical sector (Mauleón \& Bordons, 2010).

Inventor characteristics:

- $\quad\left(\right.$ lninvt $\left._{i}\right)$ : Number of inventors who take part in developing of a patent (in natural logarithm). Several authors (McMillan, 2009; Jung \& Ejermo, 2014) have found a relationship between a female presence and the number of inventors. For instance, if a patent includes only a female inventor, the average number of inventors will be fewer than of the average for men only, and even fewer than for patents that include both genders. The non-first authors show a similar trend in mixed patent. The average number of inventors of mixed-gender patents for patents filed between 2005-2007, was 3.71, while it was 2.97 for male-only and 3.01 for female-only patents. When a patent team includes both males and females, more inventors are engaged in the inventive process. In our database only $4 \%$ of the patents were filed by a women-only team. For this reason, we cannot compare patents created by women only and those created by mixed-gender teams. We, however, compare the average number of inventors for mixed-gender patents and male-only patents. Our results are comparable with the research discussed above and are shown in Table 1.

Table 1. Presence of authors by sector and gender

\begin{tabular}{|l|c|c|c|c|c|c|}
\hline & \multicolumn{2}{|c|}{ Only women } & \multicolumn{2}{c|}{ Only men } & \multicolumn{2}{c|}{ Mixed-gender } \\
\hline Sector & Quimic & Others & Quimic & Others & Quimic & Others \\
\hline Authors/patent & 2.5 & 6 & 3 & 3 & 4.86 & 4.57 \\
\hline Number of patens & 6 & 1 & 98 & 164 & 147 & 73 \\
\hline Number of authors & 15 & 6 & 286 & 486 & 715 & 334 \\
\hline Share over total & $86 \%$ & $14 \%$ & $37 \%$ & $63 \%$ & $67 \%$ & $33 \%$ \\
\hline
\end{tabular}

Source: Spanish Patent Office, own elaboration.

- $\quad s h d o c_{i}$ : share of inventors with a doctoral degree in each patent team. The importance of having a doctoral degree varies amongst sectors. Jung and Ejermo (2014) found a clear difference: Formal education and accumulated experience play a different role depending on the invention. The highly educated inventors 
work in science-based technologies such as chemistry and highly complex product technologies such as electrical engineering. Table 2 shows the share of inventors who have a doctoral degree. Most of the women have a doctoral degree (51.09\%), while a smaller percentage of male investors (39.24\%) hold it. This may be related to the technological sector where men and women are researching. Most of the women in our database engage in patents in the chemical sector. This fact might explain the high share of women inventors who hold a doctoral degree.

Table 2. Share of $\mathrm{PhD}$ inventors by gender

\begin{tabular}{|l|c|c|}
\hline & Men & Women \\
\hline Total authors & 1427 & 411 \\
\hline PhD & 560 & 210 \\
\hline Share & $39.24 \%$ & $51.09 \%$ \\
\hline
\end{tabular}

Source: TESEO database, own elaboration.

- $\quad \operatorname{colab}_{i}$ : Most of the studies on this topic are focused on publications rather than patents. Collaboration is essential for working in science, and most scientific publications have two or more authors. Several studies confirm that collaborations contribute to scientific productivity in the academic world (Lee $\&$ Bozeman, 2005). These authors have studied several forms of collaboration: universities-universities and university-public research institutions, finding a positive correlation between collaboration and productivity. Males and females have different networks of collaboration. For example, women researchers demonstrate less international collaboration than men (Abramo et al., 2013). However, in collaboration with scientists and researchers belonging to domestic institutions, collaboration is higher (De-Moya-Anegón et al., 2007). The research of Meng (2016) highlights the importance of having collaboration ties with industry for women researches. This fact, would increase their engagement in patents.

Control variables:

$a l_{i}$ : Dummy variable: 1 if the patent was applied for by the University of Almeria, 0 otherwise. 
$c a_{i}$ : Dummy variable: 1 if the patent was applied for by the University of Cadiz, 0 otherwise.

$c_{i}: \quad$ Dummy variable: 1 if the patent was applied for by the University of Cordoba, 0 otherwise.

$g r_{i}$ : Dummy variable. 1 if the patent was applied for by the University of Granada, 0 otherwise.

$h u_{i}$ : Dummy variable. 1 if the patent was applied for by the University of Huelva, 0 otherwise.

$j a_{i}$ : $\quad$ Dummy variable. 1 if the patent was applied for by the University of Jaen, 0 otherwise.

mal $_{i}$ : Dummy variable. 1 if the patent was applied for by the University of Malaga, 0 otherwise.

csic $_{i}$ : Dummy variable. 1 if the patent was applied for by the public research centres, 0 otherwise.

Female participation differs among universities and public research centres in Andalusia, as seen in Figure 1.

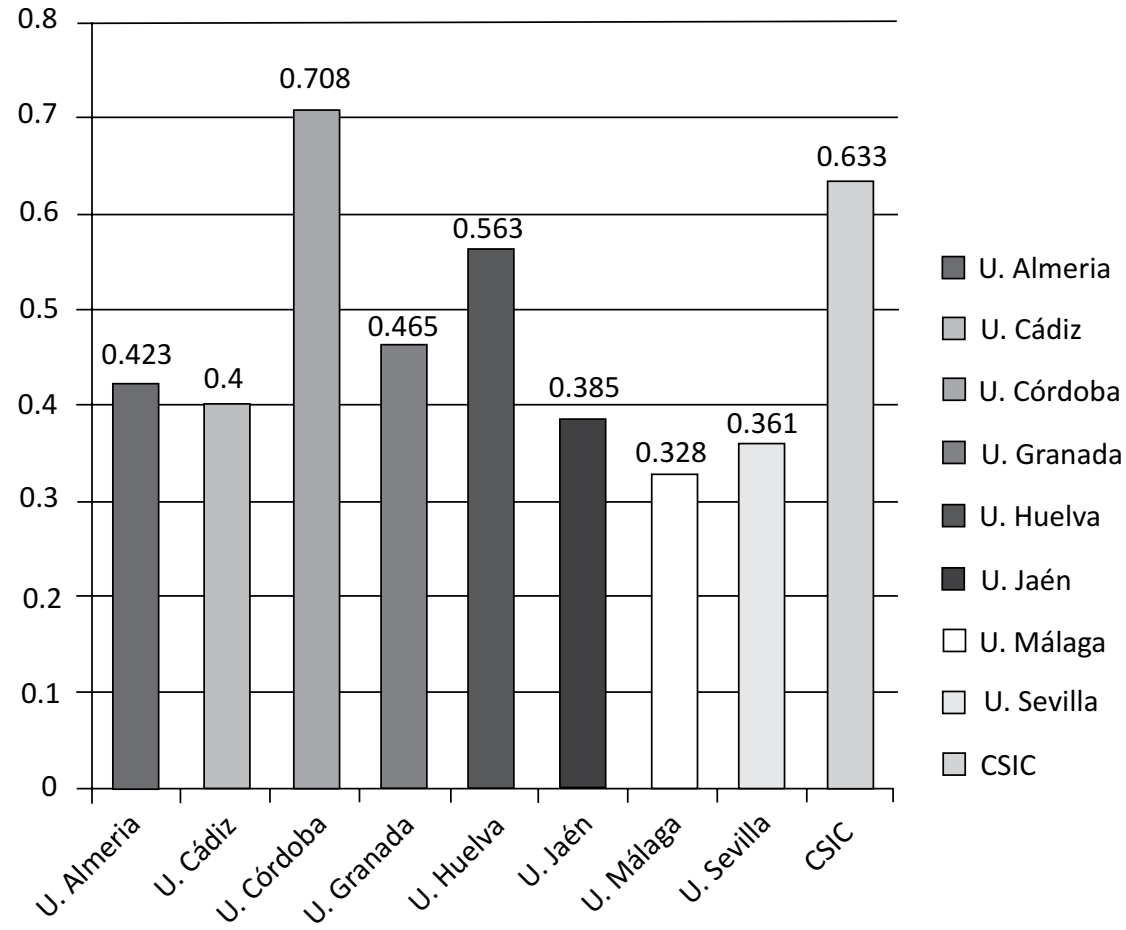

Figure 1. Female participation in patents (1990-2006)

Source: Spanish Patent Office, own elaboration. 
The highest female participation is at the University of Cordoba (70,80\%) following by CSIC (63,30\%) and the University of Huelva (56,30\%).

The lowest female participation is at the University of Malaga $(32,8 \%)$ and the University of Seville $(36,10 \%)$.

The substitution of these explanatory variables in the function lead us to the following function:

female $_{\mathrm{i}}=\mathrm{f}\left(\operatorname{lninvt}_{i}, \operatorname{shdoc}_{i}, a l_{i}, c a_{i}, c o_{i}, \operatorname{gra}_{i}, h u_{i}, j a_{i}\right.$, mal $_{i}, \operatorname{lnnp} c_{i}, \operatorname{lncp}{ }_{i}$, $f_{\text {size }_{i}}$, colab $_{i}$, ipc $_{i}$, chem $\left.{ }_{i}, u_{i}\right), \mathrm{i}=(1,2, \ldots .489)$ where $\mathrm{u}_{\mathrm{i}}$ captures the unobservable effects.

To avoid multicollinearity in the model, we have omitted the $c s i c_{i}$ variable in the estimation. The correlations between variables are shown in Table 3. According to the results, there is no collinearity between the variables.

In Table 4 we can find descriptive statistics.

Table 3. Correlations

\begin{tabular}{|l|c|c|c|c|c|c|c|c|}
\hline & female & lnnpc & lncp & ipc & fsize & chem & lninvt & shdoc \\
\hline female & 1 & & & & & & & \\
\hline lnnpc & 0.15 & 1 & & & & & & \\
\hline lncp & 0.09 & 0.09 & 1 & & & & & \\
\hline ipc & 0.02 & -0.08 & 0.11 & 1 & & & & \\
\hline fsize & -0.02 & 0.12 & 0.18 & 0.13 & 1 & & & \\
\hline chem & 0.3 & 0.4 & 0.08 & -0.02 & 0.13 & 1 & & \\
\hline lninvt & 0.46 & 0.02 & 0.03 & 0.04 & 0.05 & 0.17 & 1 & \\
\hline shdoc & 0.03 & 0.21 & -0.05 & -0.1 & 0.12 & 0.2 & -0.21 & 1 \\
\hline
\end{tabular}

Source: Spanish Patent Office andTeseo database, own elaboration.

Table 4. Descriptive statistics

\begin{tabular}{|l|c|c|c|c|}
\hline \multicolumn{1}{|c|}{ nobs =489 } & mean & Std. Dev & Min & Max \\
\hline Female & 0.4652 & 0.4652 & 0 & 1 \\
\hline Lncp & 0.8644 & 0.6439 & -2.3 & 7.5164 \\
\hline Lnnpc & 0.5773 & 2.2315 & -2.3 & 4.2800 \\
\hline Ipc & 1.2065 & 0.4249 & 1 & 3 \\
\hline Fsize & 1.6578 & 1.3116 & 1 & 11 \\
\hline
\end{tabular}


Table 4. cd.

\begin{tabular}{|l|c|c|c|c|}
\hline \multicolumn{1}{|c|}{ nobs $=\mathbf{4 8 9}$} & mean & Std. Dev & Min & Max \\
\hline Chemic & 0.5143 & 0.5003 & 0 & 1 \\
\hline lninvnt & 1.1781 & 0.6519 & 0 & 7.5600 \\
\hline shdoc & 0.8659 & 0.2114 & 0 & 1 \\
\hline Colab & 0.1578 & 0.3649 & 0 & 1 \\
\hline Al & 0.0530 & 0.2248 & 0 & 1 \\
\hline Ca & 0.1100 & 0.3140 & 0 & 1 \\
\hline Co & 0.1000 & 0.3035 & 0 & 1 \\
\hline Gr & 0.2110 & 0.4085 & 0 & 1 \\
\hline Hu & 0.0320 & 0.1783 & 0 & 1 \\
\hline Ja & 0.0260 & 0.1612 & 0 & 1 \\
\hline Mal & 0.1300 & 0.3445 & 0 & 1 \\
\hline Sev & 0.2400 & 0.4298 & 0 & 1 \\
\hline Csic & 0.1000 & 0.3724 & 0 & 1 \\
\hline
\end{tabular}

Source: Spanish Patent Office and Teseo database, wn elaboration.

\section{RESULTS}

Table 5 summarises the core results. According to the results obtained from the models included in the table, we can point out the following:

Table 5. Results

\begin{tabular}{|l|c|c|}
\hline \multicolumn{2}{|l|}{ obs: 489} & \\
\hline Endogenous variable: female & \\
\hline \multirow{3}{*}{ const } & LOGIT(I) & PROBIT(I) \\
\hline \multirow{3}{*}{$\operatorname{lninvt}_{\mathrm{i}}$} & $-3.605561^{* * *}$ & $-2.1332^{* * *}$ \\
\cline { 2 - 3 } & $(0.861808)$ & $(0.4829)$ \\
\hline \multirow{3}{*}{ shdoc $_{\mathrm{i}}$} & $2.395184^{* * *}$ & $1.4316^{* * *}$ \\
\hline \multirow{3}{*}{ al $_{\mathrm{i}}$} & $(0.2500679)$ & $(0.1390)$ \\
\cline { 2 - 3 } & $1.220821^{* *}$ & $0.7295^{* *}$ \\
\cline { 2 - 3 } & $(0.6384619)$ & $(0.3617)$ \\
\cline { 2 - 3 } & $-1.23849^{* * *}$ & $-0.7567^{* *}$ \\
\hline
\end{tabular}


Table 5. cd.

\begin{tabular}{|c|c|c|}
\hline \multicolumn{2}{|l|}{ obs: 489} & \multirow[b]{3}{*}{ PROBIT(I } \\
\hline \multicolumn{2}{|c|}{ Endogenous variable: female } & \\
\hline & LOGIT(I) & \\
\hline \multirow{2}{*}{$\mathrm{ca}_{\mathrm{i}}$} & $-7.199194^{*}$ & $-0.4417^{*}$ \\
\hline & $(0.4286015)$ & $(0.2529)$ \\
\hline \multirow{2}{*}{$\mathrm{Co}_{\mathrm{i}}$} & 0.1534566 & 0.06451 \\
\hline & $(0.4830797)$ & $(0.2832)$ \\
\hline \multirow{2}{*}{$\mathrm{gr}_{\mathrm{i}}$} & -0.2259684 & -0.1402 \\
\hline & $(0.4012684)$ & $(0.2304)$ \\
\hline \multirow{2}{*}{$\mathrm{hu}_{\mathrm{i}}$} & -1.0005 & -0.5729 \\
\hline & $(0.7560554)$ & $(0.4246)$ \\
\hline \multirow{2}{*}{$\mathrm{ja}_{\mathrm{i}}$} & $-1.40063^{* *}$ & $-0.8595^{* *}$ \\
\hline & $(0.577224)$ & $(0.3593)$ \\
\hline \multirow{2}{*}{ mal $_{i}$} & $-1.058056^{* *}$ & $-0.6266^{* *}$ \\
\hline & $(0.4763)$ & $(0.2690)$ \\
\hline \multirow{2}{*}{$\operatorname{sev}_{\mathrm{i}}$} & $-0.9876^{* * *}$ & $-0.5835^{* * *}$ \\
\hline & $(0.3826586)$ & $(0.2217)$ \\
\hline \multirow{2}{*}{ chemc $_{i}$} & $0.8970 * * *$ & $0.5372^{* * *}$ \\
\hline & $(0.2510)$ & $(0.1473)$ \\
\hline \multirow{2}{*}{$\operatorname{lnnpc} c_{i}$} & 0.040049 & 0.0221 \\
\hline & $(0.0567532)$ & $(0.0331)$ \\
\hline \multirow{2}{*}{$\operatorname{lncp}_{\mathrm{i}}$} & $0.1112376^{*}$ & $0.0678^{*}$ \\
\hline & $(0.0638296)$ & $(0.0374)$ \\
\hline \multirow{2}{*}{ fsize $_{i}$} & $-0.242245^{* * *}$ & $-0.1415^{* * *}$ \\
\hline & $(0.0893835)$ & $(0.0537)$ \\
\hline \multirow{2}{*}{$\mathrm{ipc}_{\mathrm{i}}$} & 0.1151505 & 0.0499 \\
\hline & $(0.2772588)$ & $(0.1601)$ \\
\hline \multirow{2}{*}{ colab $_{\mathrm{i}}$} & 0.095666 & 0.0635 \\
\hline & $(0.34416)$ & $(0.2005)$ \\
\hline McFadden Rsquared & 0.2688 & 0.2706 \\
\hline \multicolumn{3}{|l|}{$* * * 1 \%$ level significance } \\
\hline \multicolumn{3}{|l|}{$* * 5 \%$ significance level } \\
\hline${ }^{*} 10 \%$ significance leve & & \\
\hline
\end{tabular}

Source: Spanish Patent Office and Teseo database, own elaboration. 
The ipc variables (number of assignments in the International Patent Classification), colab (whether or not there is a collaboration between different research centres) and lnnpc (number of scientific articles cited in the patents documents), have no influence on the endogenous variable.

The variables that have a positive influence - i.e., increase the probability of female participation in patent teams - are: the percentage of inventors (in semi-elasticity terms, lninvt $_{i}$ ), the share of Ph.D.s, $\operatorname{shdoc}_{i}$, if the patent belongs to the chemical sector, chem, and the citing patents $\operatorname{lncp}_{i}$ (in semi-elasticity terms, too).

The influence of $f_{s i z e_{\mathrm{i}}}$ over the probability of female participation in patents is negative. The following explains these findings.

There is a lower probability that there will be a female patent presence in the universities of Almeria, Cadiz, Jaen, Malaga, and Seville than in the public research centres.

Analysing the results, we can conclude that hypotheses 1, 2, 3, 4, 6.2, and 6.4 are confirmed and hypotheses $5,6.1$, and 6.3 are not confirmed.

Table 6. Summarises the hypotheses

\begin{tabular}{|l|l|c|}
\hline $\mathbf{H}_{1}$ & The number of inventors influences female participation in the invention & $\checkmark$ \\
\hline $\mathbf{H}_{2}$ & There are differences in female participation among technological sectors & $\checkmark$ \\
\hline $\mathbf{H}_{3}$ & Female participation is different among universities and research centres & $\checkmark$ \\
\hline $\mathbf{H}_{4}$ & The share of Ph.D.s in patent teams affects female participation & $\checkmark$ \\
\hline $\mathbf{H}_{5}$ & Collaboration between institutions influences female participation. & $\mathbf{X}$ \\
\hline $\mathbf{H}_{6}$ & Technical characteristics of the patent influence female participation: & $\mathbf{X}$ \\
\hline $\mathbf{H}_{6.1 .}$ & Patent citations act on female participation. & $\checkmark$ \\
\hline $\mathbf{H}_{6.2 .}$ & Citing patents affects female participation. & $\mathbf{X}$ \\
\hline $\mathrm{H}_{6.3 .}$ & IPC codes have an impact on female participation & $\checkmark$ \\
\hline $\mathrm{H}_{6.4 .}$ & $\begin{array}{l}\text { The number of countries where the patent is applied for helps determine } \\
\text { female participation. }\end{array}$ & \\
\hline$\checkmark:$ Null hypothesis rejected & \\
\hline $\mathbf{X}: \mathbf{N u l l}$ hypothesis accepted & \\
\hline
\end{tabular}




\section{DISCUSSION AND CONCLUSIONS}

In this work we have answered the question:

Which factors encourage female participation in patents?

Our models call for rejecting null hypothesis $1,2,3,4,6.2$, and 6.4. Null hypotheses 5, 6.1, and 6.3 are not rejected.

According to these findings, patent citations, IPC codes and collaboration between institutions are not relevant in explaining the probability of engaging female researches in patent teams. In this paper we have only studied the collaboration between universities and/or public research centers (extramural). We do not have results for intramural collaboration. Literature shows us that this type of collaboration is essential, moreover in the case of female researches they often collaborate with their male colleagues in the place of work. Although we do not show a relationship between collaboration and female participation, it is important to encourage intramural and extramural female scientific collaboration in order to increase the visibility and productivity of female researchers.

In contrast to the results exposed in the previous paragraph, the number of inventors and the chemical sector play a relevant positive effect in female participation in patents. These last results are along the lines of the studies mentioned in section 4 above. The share of Ph.Ds. in a patent team has a positive effect as well. This finding sheds light on the type of patents where female is mainly involved, that is to say, patent based on basic science.

Conversely, the number of countries where the patent is applied for shows a relevant negative effect in female participation. This is because the patents that seek protection in different countries belong to the engineering sector, where female participation is low, irrelevant.

There are differences at the institutional level, too. Some universities (Almeria, Cadiz, Jaen, Malaga, and Seville) show a relevant negative effect on female participation when compared to public research centres (CSIC). Public research centres have more females working on patents than the universities cited above.

These results lead us to say that, as in all of the countries/regions, there is scarce female representation in patents among the patent-holders of Andalusian universities and public research centres. Given the capacity of human resources to generate wealth in a specific area, it 
is necessary to implement policies to promote a greater involvement of women in the fields of science and technology and in engineering.

With a view to future research, we would like to underline our interest in extending the study to all Spanish regions in order to establish comparisons. Also, it would be interesting to extend the period of study and compare the actual sample (1990-2006) with the following decade (2007-2016) to check whether or not the gap between male and female researches is decreasing.

\section{REFERENCES}

Abramo, G., D’Angelo, C.A. \& Murgia, G. (2013). Gender differences in research collaboration, Journal of Informetrics, 7(4), pp. 811-822.

Agnete Alsos, G., Ljunggren, E. \& Hytti, U. (2013). Gender and innovation: state of the art and a research agenda, ed. Gry Agnete Alsos, Ulla Hytti, International Journal of Gender and Entrepreneurship, 5(3), pp. 236-256.

Azoulay, P., Ding, W. \& Stuart, T. (2007). The determinants of faculty patenting behavior: Demographics or opportunities?, Journal of Economic Behavior and Organization, 63(4), pp. 599-623.

Busolt, U. \& Kugele, K. (2009). The gender innovation and research productivity gap in Europe, International Journal of Innovation and Sustainable Development, 4(2/3), pp. 109-122.

Criscuolo, P. \& Verspagen, B. (2008). Does it matter where patent citations come from? Inventor vs. examiner citations in European patents, Research Policy, 37(10), pp. 1892-1908.

De-Moya-Anegón, F., Chinchilla-Rodríguez, Z., Corera-Álvarez, E., Gómez-Crisóstomo, R., González-Molina, A., Muñoz-Fernández, F.J., SCImago Research Group. (2007). Indicadores bibliométricos de la actividad científica española: 1990-2004.

Ding, W.W., Murray, F. \& Stuart, T.E. (2006). Gender differences in patenting in the academic life sciences, Science, 313(5787), pp. 665-667.

Fox, M.F. (2010). Women and men faculty in academic science and engineering: Social-organizational indicators and implications, American Behavioral Scientist, 53(7), pp. 997-1012.

Frietsch, R., Haller, I., Funken-Vrohlings, M., \& Grupp, H. (2009). Gender-specific patterns in patenting and publishing,. Research Policy, 38(4), pp. 590-599.

Hall, B.H., Jaffe, A. \& Trajtenberg, M. (2005). Market Value and Patent Citations, The RAND Journal of Economics, 36, pp. 16-38. 
Hunt, J., Garant, J. P., Herman, H., \& Munroe, D. J. (2012). Why don't women patent? National Bureau of Economic Research Working Paper Series, 17888.

Jung, T. \& Ejermo, O. (2014). Demographic patterns and trends in patenting: Gender, age, and education of inventors, Technological Forecasting and Social Change, 86, pp. 110-124.

Kugele, K. (2010). Analysis of women's participation in high-technology patenting, Contemporary Issues in Entrepreneurship Research, 1, pp. 123-151.

Lee, S. \& Bozeman, B. (2005). The impact of research collaboration on scientific productivity, Social Studies of Science, 35(5), pp. 673-702.

Mariani, M. \& Romanelli, M. (2007). "Stacking" and "picking" inventions: The patenting behavior of European inventors, Research Policy, 36(8), pp. 1128-1142.

Mauleón, E. \& Bordons, M. (2010). Male and female involvement in patenting activity in Spain, Scientometrics, 83(3), pp. 605-621.

McMillan, G.S. (2009). Gender differences in patenting activity: An examination of the US biotechnology industry, Scientometrics, 80(3), pp. 683-691.

Meng, Y. \& Shapira, P. (2011). Women and Patenting in Nanotechnology: Scale, Scope and Equity. In Nanotechnology and the Challenges of Equity, Equality and Development. Springer, Netherlands, pp. 23-46.

Meng, Y. (2016). Collaboration patterns and patenting: Exploring gender distinctions, Research Policy, 45(1), pp. 56-67.

Morgan, R.P., Kruytbosch, C. \& Kannankutty, N. (2001). Patenting and invention activity of US scientists and engineers in the academic sector: comparisons with industry, The Journal of Technology Transfer, 26(1-2), pp. 173-183.

Naldi, F., Luzi, D., Valente, A., \& Parenti, I.V. et al. (2005). Scientific and technological performance by gender. In: Handbook of quantitative science and technology research. Springer, Netherlands, pp. 299-314.

Narin, F., Hamilton, K.S. \& Olivastro, D. (1997). The increasing linkage between US technology and public science, Research Policy, 26(3), pp. 317-330.

Nonaka, I. (1991). The knowledge-creating company, Harvard Business Review, 69, pp. 96-104.

Okoń-Horodyńska, E. \& Zachorowska-Mazurkiewicz, A.M. (2015). Innovation, innovativeness and gender - Approaching innovative gender, Scientific Annals of the "Alexandru Ioan Cuza" University of Iasi. Economic Sciences, $62(1)$, p. 1.

Pearson Jr, W., \& Fechter, A. (1994). Who Will Do Science? Educating the Next Generation. Baltimore: Johns Hopkins University Press.

Stephan, P.E., Gurmu, S., Sumell, A. J., \& Black, G. (2007) (2007). Who's patenting in the University? Evidence from the survey of doctorate recipients, Economics of Innovation and New Technology, 16(2), pp. 71-99. 
Thursby, J.G. \& Thursby, M.C. (2005). Gender patterns of research and licensing activity of science and engineering faculty, The Journal of Technology Transfer, 30(4), pp. 343-353.

Toribio, R. \& Puentes, C. (2016). The effects of gender on the quality of university patents and public research centres in Andalusia: Is it better with a female presence?, Economics and Sociology, 9(1), pp. 220-236.

Whittington, K.B. \& Smith-Doerr, L. (2005). Gender and commercial science: Women's patenting in the life sciences, The Journal of Technology Transfer, 30(4), pp. 355-370.

Wisła, R. \& Sierotowicz, T. (2015). Gender in the creation of intellectual property of the selected European Union countries, Economics and Sociology, 8(2), pp. 115-125. 


\title{
ROZUMIENIE CZYNNIKÓW ZAANGAŻOWANIA KOBIET W DZIALALNOŚĆ PATENTOWĄ W ANDALUZJI (HISZPANIA)
}

\begin{abstract}
Abstrakt
Tło badań: Jednym z ekonomicznych aspektów zrównoważonego rozwoju są innowacje. Jeśli rozumiemy innowacyjność kraju jako zdolność do osiagnięcia wzrostu gospodarczego, dobrobytu społecznego i zrównoważonego rozwoju, czynnik ludzki jest kluczowy do zarządzania tymi celami; w szczególności wkład naukowców. Różnice płci w nauce i technologii pozostają stabilne w czasie. W niewielkim stopniu prowadzi się jednak badania dotyczące szczególnego zaangażowania kobiet w innowacje technologiczne. Od 1990 do 2006 roku w szkołach wyższych i publicznych ośrodkach badawczych w Andaluzji w Hiszpanii odnotowano 411 kobiet i 1427 mężczyzn.
\end{abstract}

Cel badań: Celem tego artykułu jest określenie, jakie czynniki zachęcają kobiety do udziału w działalności patentowej.

Metodologia: Badania opierają się na analizie - szacując modele Logit i Probit - informacji, które zawierają 498 wniosków patentowych i 1838 wynalazców z uniwersytetów i publicznych ośrodków badawczych CSIC w Andaluzji (Hiszpania) w latach 1990-2006.

Kluczowe wnioski: Zmienne, które okazały się znaczące i pozytywne w odniesieniu do prawdopodobieństwa udziału kobiet, to liczba autorów w każdym patencie w sektorze chemicznym i udział w pracy doktora. Elementy, które nie sa istotne w wyjaśnieniu prawdopodobieństwa obecności kobiet w działalności patentowej, to współdziałanie różnych centrów badawczych i liczba zgłoszeń patentowych, które dana osoba posiada w Międzynarodowej Klasyfikacji Patentowej.

Słowa kluczowe: płeć i patenty, innowacje, obecność kobiet. 